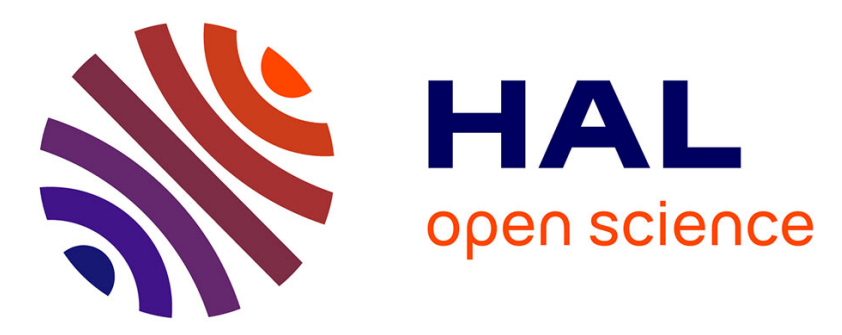

\title{
Circular in situ neutron powder diffraction cell for study of reaction mechanism in electrode materials for Li-ion batteries
}

\author{
Vikram Godbole, Michael Hess, Claire Villevieille, Hermann Kaiser, \\ Jean-François Colin, Petr Novak
}

\section{To cite this version:}

Vikram Godbole, Michael Hess, Claire Villevieille, Hermann Kaiser, Jean-François Colin, et al.. Circular in situ neutron powder diffraction cell for study of reaction mechanism in electrode materials for Li-ion batteries. RSC Advances, 2013, 3 (3), pp.757-763. 10.1039/C2RA21526H . hal-02612991

\section{HAL Id: hal-02612991 \\ https://hal.science/hal-02612991}

Submitted on 28 May 2020

HAL is a multi-disciplinary open access archive for the deposit and dissemination of scientific research documents, whether they are published or not. The documents may come from teaching and research institutions in France or abroad, or from public or private research centers.
L'archive ouverte pluridisciplinaire HAL, est destinée au dépôt et à la diffusion de documents scientifiques de niveau recherche, publiés ou non, émanant des établissements d'enseignement et de recherche français ou étrangers, des laboratoires publics ou privés. 


\title{
RSC Advances
}

Cite this: RSC Advances, 2013, 3, 757

\section{Circular in situ neutron powder diffraction cell for study of reaction mechanism in electrode materials for Li-ion batteries $\dagger$}

\author{
Vikram A. Godbole,ł Michael Heß, Claire Villevieille, Hermann Kaiser, \\ Jean-François Colin§ and Petr Novák*
}

\begin{abstract}
The study of reaction mechanisms in materials for Li-ion batteries mainly involves localization of lighter elements like $\mathrm{Li}, \mathrm{O}$, or even $\mathrm{H}$ in the structure. Thus, in order to facilitate in situ localization of lighter elements and in situ study of structural evolution in the electrode materials, a circular in situ neutron diffraction cell capable of cycling small amounts of electrode materials (0.2-0.3 g) was developed for primary use at the D20 beamline at ILL, Grenoble, France. The circular cell design was tested using $\mathrm{LiFePO}_{4}$ and graphite as the model electrode materials. The effect of using deuterated electrolyte versus protonated electrolyte on the quality of the in situ neutron diffraction data was also investigated. First in situ neutron powder diffraction measurements at ILL, Grenoble, were successfully conducted where each neutron diffraction pattern was recorded in only $24 \mathrm{~min}$, delivering very good time resolution. It was also found that a circular cell design holding only a small amount of material soaked in deuterated electrolyte was best to perform quantitative analysis using the Rietveld method over the complete 2 theta range. The pattern shows no apparent anisotropic absorption of the diffracted neutron beams.
\end{abstract}

Received 23rd July 2012,

Accepted 7th November 2012

DOI: $10.1039 / \mathrm{c} 2 \mathrm{ra} 21526 \mathrm{~h}$

www.rsc.org/advances lighter elements like $\mathrm{Li}, \mathrm{H}$, or $\mathrm{O}$ in the structure. These elements are essentially non-scattering to X-rays, however they show higher scattering to neutrons and hence can be easily localized in the structure using neutrons. Another interesting aspect of neutron diffraction is the possibility to distinguish between neighboring elements like $\mathrm{Mn}$, Co, and $\mathrm{Ni}$, which have essentially similar scattering in X-rays. However the interaction of neutrons with matter, unlike X-rays, is very weak and thus usually a large amount of material is needed for the neutron powder diffraction (NPD) measurements, along with longer data acquisition time. This makes it difficult to design a good and reliable in situ NPD cell.

There exist different in situ NPD cell designs for battery materials, whether for Li-ion batteries or other battery systems. ${ }^{3-6}$ However, in all the published cell designs several drawbacks are apparent. Most of the cell designs result in the presence of many cell parts within the neutron beam, viz. counter electrode, separator, both current collectors, cell body, etc. This results in appearance of additional undesired Bragg reflections in the diffraction pattern. Moreover, some cell designs use large quantities of electrolyte, which in turn results in higher background intensity and normally in high cost when using deuterated solvents. Thus, recently a rectangular in situ NPD cell was designed in our laboratory for use at the High Resolution Powder Diffractometer for Thermal Neutrons (HRPT) beamline at Swiss Spallation Neutron Source (SINQ), PSI Villigen. ${ }^{7}$ This cell has an 
advantage over the other designs in that only the electrode material soaked with electrolyte and the aluminum or titanium current collector are in the neutron beam. Moreover, by tuning the active material to conductive carbon ratio in the cell, in situ NPD patterns with lower background intensities were obtained. ${ }^{8}$ Increased amount of carbon additives reduce the ohmic resistance, while increasing the background intensity. Thus an optimum ratio between the active material and the conductive additive is needed as discussed in ref. 8. Nevertheless, this cell design suffered from the large amount of electrode material $(\sim 3 \mathrm{~g})$ needed for a good NPD pattern, which drastically affected the electrochemistry of the material. ${ }^{7,8}$ Secondly, due to the rectangular design of the previous in situ NPD cell, an anisotropic absorption of the diffracted neutron beams could not be avoided, resulting in a challenging full pattern Rietveld refinement of the in situ NPD patterns. In order to overcome these drawbacks, a circular in situ NPD cell was designed to be used at a high intensity neutron source. In this paper, the proof of concept of this circular cell design has been presented along with the first in situ NPD results obtained for $\mathrm{LiFePO}_{4}$ and graphite as model active materials.

\section{Experimental}

\section{Cell design and electrochemistry}

Fig. 1(A) shows the cross-section view of the new circular in situ NPD cell design, whereas Fig. 1(B) shows the position of the cell in the neutron beam. The cell depicted in Fig. 1(A) consists of several parts. The outer cell body (5) is made up of aluminum and is separated from the inner cell body by (6)

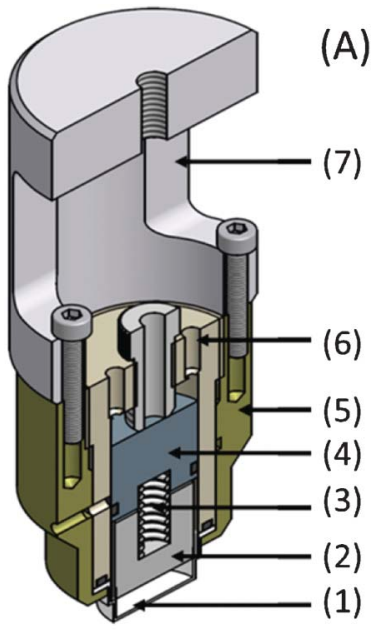

(B)

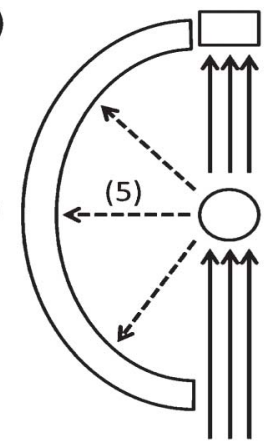

Fig. 1 (A) Cross-section of the new circular in situ NPD cell: (1) Al/Ti container for the electrode material (the only part in neutron beam), (2) Ti plunger for Li counter electrode, (3) spring, (4) Ti current collector, (5) Al cell body part, (6) PEEK cell, (7) polymeric attachment for D20 beamline. (B) Top-view schematics showing the position of in situ NPD cell (2) in relationship to the incident beam (1) and the detector (6). Out-going beam (3), beam stopper (4), and diffracted beam (5) are also marked. polyetheretherketone (PEEK). The inner cell body consists of a titanium plunger (2) pushed down from the titanium current collector (4) by a spring (3) to guarantee a homogeneous pressure on the electrode material. The titanium plunger acts as the support for the counter electrode, normally a disk of lithium metal. The sample holder (1) is a thin-walled $(0.5 \mathrm{~mm})$ cylinder and is the only part of the cell, besides the porous electrode, that is in the neutron beam during diffraction measurement. This part is $15 \mathrm{~mm}$ in diameter and has a height of $3.5 \mathrm{~mm}$. It holds the electrode material and simultaneously acts as the current collector. Ideally, this container would be a metal that is inherently non- or lowscattering in neutrons, e.g., vanadium. ${ }^{9}$ Nevertheless, the cost of bulk vanadium is rather high and the machining difficult. Another possibility could be the use of $\mathrm{Ti}-\mathrm{Zr}$ null matrix alloy. ${ }^{10} \mathrm{Ti}-\mathrm{Zr}$ alloy in atomic ratio $62 \%: 38 \%$ is essentially non-scattering for neutrons. This alloy being commercially unavailable, making and machining a pure Ti-Zr alloy that is non-scattering in a neutron beam is extremely difficult. Therefore, for the development of the in situ cell and tests of the new design, aluminum was selected for the sample holder (1) because of its low neutron absorption coefficient and small scattering cross-section. Due to the alloying of aluminum with lithium at low potentials, a titanium container was designed with the same dimensions for cycling of negative electrode materials. O-Rings are used between different parts to seal the cell hermetically. The dimensions of the sample holder for the circular in situ NPD cell have been drastically reduced from its rectangular predecessor $\left[53 \times 19 \times 5.8 \mathrm{~mm}^{3}(\mathrm{l} \times \mathrm{w} \times \mathrm{h})\right]$, resulting in reduction of the sample holder volume from 5.84 $\mathrm{cm}^{3}$ to $0.62 \mathrm{~cm}^{3}$.

In order to check the electrochemical performance of different active materials in the circular in situ NPD cell, $\mathrm{Li}_{1.1}\left(\mathrm{Ni}_{1 / 3} \mathrm{Mn}_{1 / 3} \mathrm{Co}_{1 / 3}\right)_{0.9} \mathrm{O}_{2}$, carbon-coated $\mathrm{LiFePO}_{4}$, and $\mathrm{Li}_{4} \mathrm{Ti}_{5} \mathrm{O}_{12}$ were tested in an aluminum container while graphite was tested in a titanium container. To assemble the cell, the active material and Super-P carbon (TIMCAL, Switzerland) powders were hand mixed in a mortar, and were packed into the container. In case of the graphite no Super-P carbon was used. A glass fiber separator was placed on top of the material and was soaked with either standard protonated ethylene carbonate (EC)/dimethyl carbonate (DMC) $1 \mathrm{M} \mathrm{LiPF}_{6}$ (Ferro, USA) or deuterated ethylene carbonate (d-EC)/dimethyl carbonate (d-DMC) $1 \mathrm{M} \mathrm{LiPF} 6$ or deuterated propylene carbonate (d-PC)/dimethyl carbonate (d-DMC) $1 \mathrm{M} \mathrm{LiClO}_{4}$ (Armar AG, Switzerland). A lithium metal disk acted as the counter electrode. The complete cell assembly was performed in an Ar-filled glove box. The $\mathrm{LiFePO}_{4}, \mathrm{Li}_{4} \mathrm{Ti}_{5} \mathrm{O}_{12}$, and $\mathrm{Li}_{1.1}\left(\mathrm{Ni}_{1 / 3} \mathrm{Mn}_{1 / 3} \mathrm{Co}_{1 / 3}\right)_{0.9} \mathrm{O}_{2}$ cells were cycled at $\mathrm{C} / 24$ rate, and the graphite cell at $\mathrm{C} / 200$ rate with respect to theoretical specific charge of the active material used. In this study, Li metal and lithium-containing active materials were made up of naturally occurring lithium (mixture of ${ }^{6} \mathrm{Li}$ and ${ }^{7} \mathrm{Li}$ ) and no isotope-enriched lithium was used.

\section{Ex situ neutron powder diffraction (NPD)}

In order to have starting models for quantitative analysis of diffraction patterns obtained using the in situ NPD cell using the Rietveld method, ex situ NPD measurements were 
performed at $1.36 \AA$ for 24 min on dry starting $\mathrm{LiFePO}_{4}$ powder $(2 \mathrm{~g})$ and dry $\mathrm{LiFePO}_{4}$ electrode mixture $\left[0.25 \mathrm{~g}\right.$ of $\mathrm{LiFePO}_{4}(85$ wt\%) and Super-P carbon (15 wt\%)] electrochemically precharged till $4.5 \mathrm{~V}$ vs. $\mathrm{Li} / \mathrm{Li}^{+}$, held in a vanadium cylinder. Rietveld refinement was performed on these patterns using the structural models proposed by Andersson et al. ${ }^{11}$ For the starting $\mathrm{LiFePO}_{4}$ only a single phase Rietveld refinement was used, whereas for the electrode obtained after the first charge a 2-phase Rietveld refinement with $\mathrm{LiFePO}_{4}$ and $\mathrm{FePO}_{4}$ phases was performed.

Ex situ NPD measurements were then conducted at $1.36 \AA$ for $24 \mathrm{~min}$ on the $\mathrm{LiFePO}_{4}$ electrode $\left[0.25 \mathrm{~g}\right.$ of $\mathrm{LiFePO}_{4}(85$ $\mathrm{wt} \%)$ and Super-P carbon (15 wt\%)] in the completely assembled cell, soaked with deuterated propylene carbonate (d-PC)/deuterated dimethyl carbonate (d-DMC) $1 \mathrm{M} \mathrm{LiClO}_{4}$ as the electrolyte. A similar experiment was carried out using an electrochemically pre-charged $\mathrm{LiFePO}_{4}$ porous electrode soaked in deuterated electrolyte. The structural models obtained from Rietveld refinement of dry samples in vanadium cylinders were used for the Rietveld refinement of the patterns from electrolyte-soaked electrodes held in Al containers. Only the zero, scale factor, and the peak width parameters were refined. In both the cases an additional Al phase was introduced to refine the corresponding peaks from the $\mathrm{Al}$ container.

In order to differentiate between the quality of NPD pattern obtained using protonated and deuterated electrolyte, a cell was assembled using starting $\mathrm{LiFePO}_{4}$ and Super-P carbon mixture soaked in protonated EC/DMC $1 \mathrm{M} \mathrm{LiClO}_{4}$ electrolyte and ex situ NPD pattern was recorded for it at $1.36 \AA$ for $24 \mathrm{~min}$ at the D20 beamline.

\section{In situ neutron powder diffraction (NPD)}

For the in situ NPD measurements, $0.28 \mathrm{~g}$ mixture of carboncoated $\mathrm{LiFePO}_{4}$ (85 wt\%) and Super-P carbon (15 wt\%) was taken as the electrode mass. No PVDF binder was used to avoid hydrogen in the sample and reduce diffuse scattering from amorphous polymers. The in situ cell was assembled as described previously using EC/DMC $1 \mathrm{M} \mathrm{LiClO}_{4}$ electrolyte. For the in situ measurements, the cell was charged versus $\mathrm{Li}$ counter electrode at $\mathrm{C} / 24$ rate with respect to $170 \mathrm{~mA} \mathrm{~h} \mathrm{~g}^{-1}$ till $4.5 \mathrm{~V} v s . \mathrm{Li} / \mathrm{Li}^{+}$and then held at open circuit potential (OCP) for $2 \mathrm{~h}$. Due to the limited time allocated at the beamline only the first charge for $\mathrm{LiFePO}_{4}$ was tested, where an in situ NPD pattern was recorded during the operation of the cell for a period of 24 min or $0.01667 \mathrm{Li}^{+}$exchange.

In another study in situ NPD measurement was performed on graphite, using deuterated electrolyte. For this purpose 0.24 $\mathrm{g}$ of SFG44 graphite powder (TIMCAL, Switzerland) was placed in a titanium container. The cell was assembled as described above using deuterated d-EC/d-DMC $1 \mathrm{M} \mathrm{LiPF}_{6}$ (6.8 ppm water) electrolyte. As the aim of this study was to investigate the structural evolution starting from graphite to stage $2 \mathrm{~L}$, the in situ NPD patterns were recorded over $30 \mathrm{~min}$ at $1.36 \AA$ and 50 ${ }^{\circ} \mathrm{C}( \pm 1)$, only between 0.23 and $0.11 \mathrm{~V} v s$. $\mathrm{Li}^{\prime} / \mathrm{Li}^{+}$[points 1 to 5 in Fig. 2(B)].
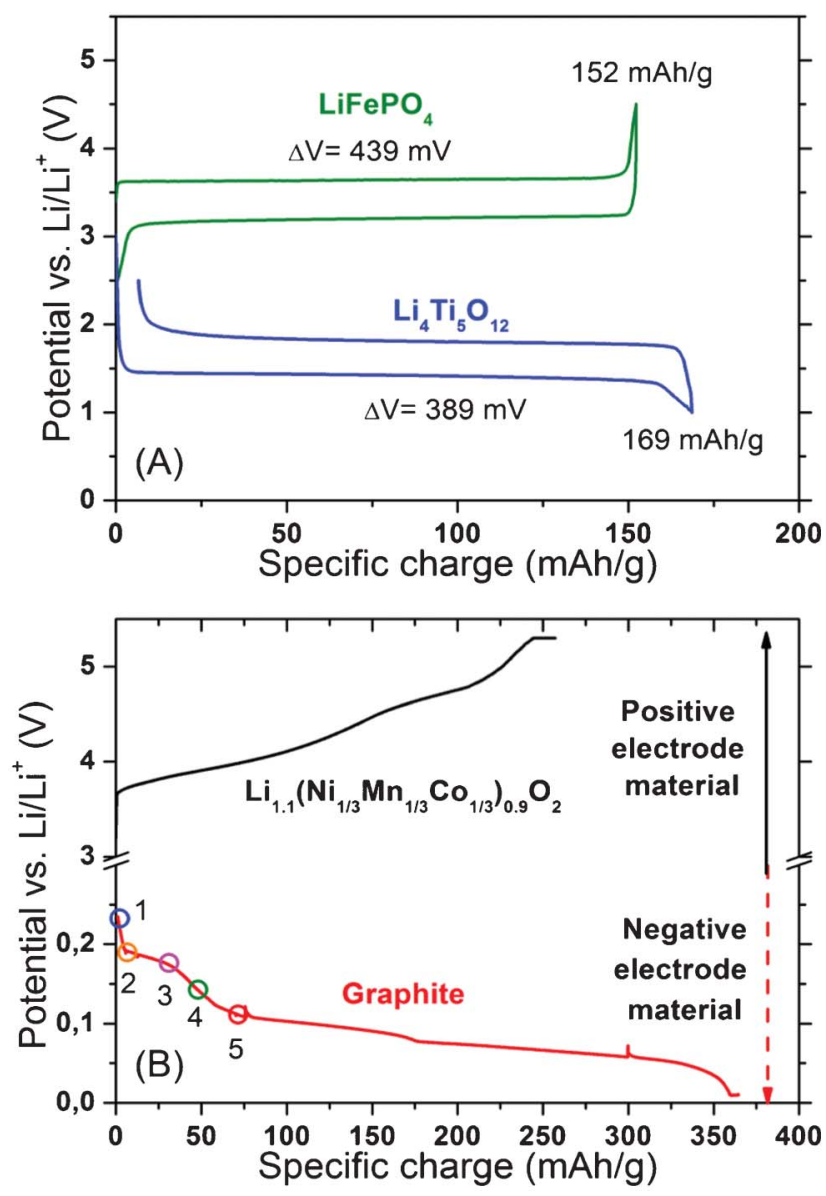

Fig. 2 (A) First electrochemical cycle of $\mathrm{LiFePO}_{4}$ and $\mathrm{Li}_{4} \mathrm{Ti}_{5} \mathrm{O}_{12}$, (B) first delithiation and lithiation of $\mathrm{Li}_{1.1}\left(\mathrm{Ni}_{1 / 3} \mathrm{CO}_{1 / 3} \mathrm{Mn}_{1 / 3}\right)_{0.9} \mathrm{O}_{2}$ and graphite, respectively, at different $\mathrm{C}$-rates (indicated in the manuscript) in the circular in situ NPD cell versus Li counter-electrode. The in situ NPD measurements on graphite (Fig. 7) were performed between the points 1 and 5 .

\section{Results and discussion}

In order to test the feasibility of the circular cell design to cycle various electroactive materials, $\mathrm{Li}_{1.1}\left(\mathrm{Ni}_{1 / 3} \mathrm{Mn}_{1 / 3} \mathrm{Co}_{1 / 3}\right)_{0.9} \mathrm{O}_{2}$, $\mathrm{LiFePO}_{4}, \mathrm{Li}_{4} \mathrm{Ti}_{5} \mathrm{O}_{12}$, and graphite were cycled in aluminum or titanium containers at different C-rates. In the case of $\mathrm{LiFePO}_{4}$ and $\mathrm{Li}_{4} \mathrm{Ti}_{5} \mathrm{O}_{12}$, the internal resistance in the in situ cell (seen in Fig. 2(A) as the difference between the lithiation and delithiation curve) is slightly higher when compared to a standard electrochemical cell, which is expected due to the use of $\sim 0.3 \mathrm{~g}$ electrode material. In the case of $\mathrm{LiFePO}_{4}$, the overpotential during charge $\left(\eta_{\mathrm{c}}=193 \mathrm{mV}\right)$ was seen to be smaller than that for discharge $\left(\eta_{\mathrm{c}}=246 \mathrm{mV}\right)$. It was reported by Shin et al. that at higher C-rates for carbon-coated $\mathrm{LiFePO}_{4}$ phase transition during discharge is difficult compared to charge. ${ }^{12}$ A similar effect is also expected for a larger quantity of carbon-coated $\mathrm{LiFePO}_{4}$ cycling at lower C-rates, owing to the higher local surficial current densities. However, despite the higher internal resistance in the in situ cell, both the electrode materials deliver $\geqslant 90 \%$ of their theoretical specific charge during cycling, with $>95 \%$ coulombic efficiency during the first cycle. The electrode 
composition for $\mathrm{Li}_{1.1}\left(\mathrm{Ni}_{1 / 3} \mathrm{Mn}_{1 / 3} \mathrm{Co}_{1 / 3}\right)_{0.9} \mathrm{O}_{2}$ and graphite electrodes was not optimized and hence only their first delithiation and lithiation are shown, respectively (first electrochemical cycle of these materials in coin-like cells shown in ESI, Fig. A†). As seen from Fig. 2(B), the circular cell can be used over the complete range of interest for the battery materials, i.e., from 0.01 up to $5.2 \mathrm{~V} v s$. $\mathrm{Li} / \mathrm{Li}^{+}$with the same cell design. From these electrochemical results it can be concluded that the circular cell design shows significant improvement over the rectangular predecessor. $^{7}$

Fig. 3 shows the Rietveld refinement method performed on the NPD patterns of the dry $\mathrm{LiFePO}_{4}$ powder and the $\mathrm{LiFePO}_{4}$ electrode after 1 st charge, held in a vanadium cylinder. As expected the analysis confirmed that both the starting $\mathrm{LiFePO}_{4}$ and the $\mathrm{FePO}_{4}$ present in the electrode mass at the end of first charge crystallize in the orthorhombic Pnma space group. Table 1 and 2 detail the results of the Rietveld analysis. For the $\mathrm{LiFePO}_{4}$ electrode after the 1st charge [Fig. 3(B)], the signal-tonoise ratio is low owing to the fact that the electrode contained $15 \%$ carbon, which is a neutron scatterer, that a small amount $(0.25 \mathrm{~g})$ of material was used, and that the material has
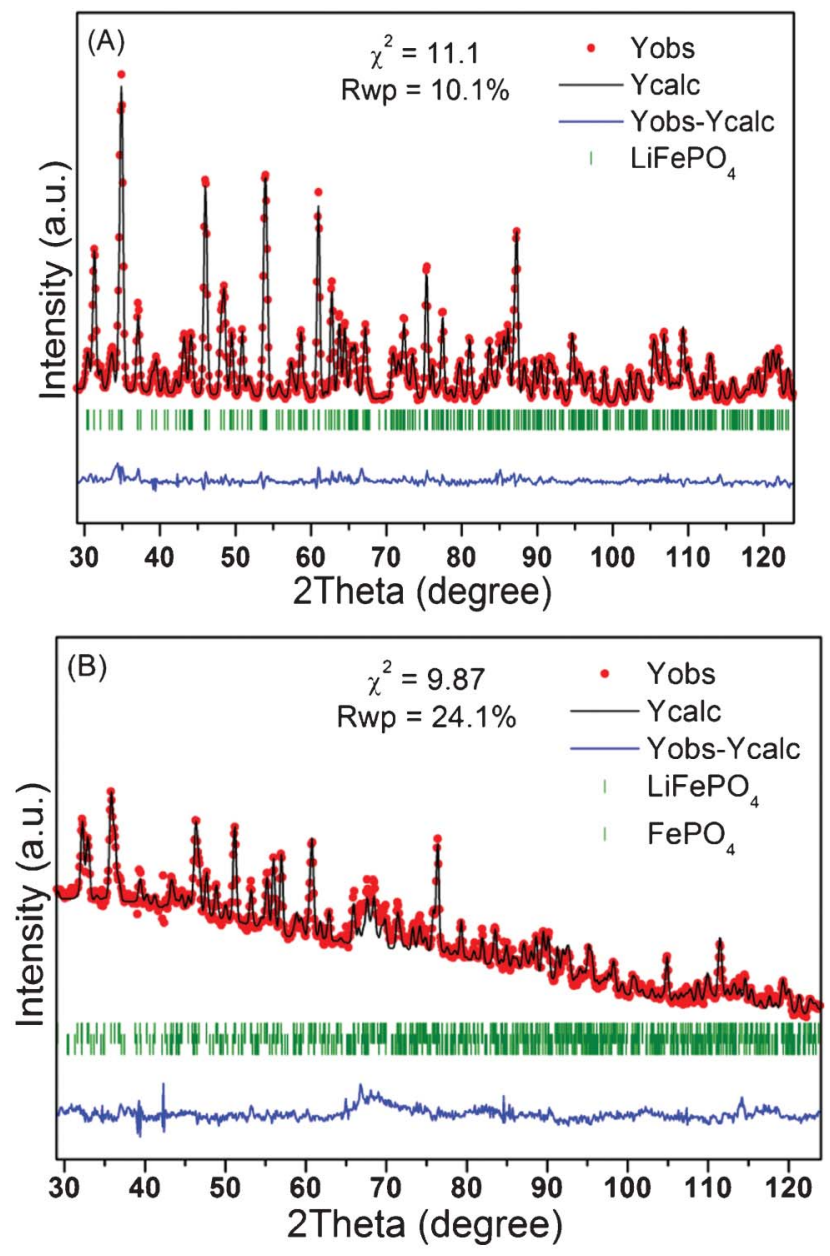

Fig. 3 Rietveld refinement of ex situ NPD pattern $(\lambda=1.36 \AA)$ of $(A)$ dry $\mathrm{LiFePO}_{4}$ pristine powder and (B) dry $\mathrm{LiFePO}_{4}$ electrode mass after 1 st charge till $4.5 \mathrm{~V}$ vs. $\mathrm{Li} / \mathrm{Li}^{+}$. The samples were enclosed in a vanadium cylinder.

undergone an electrochemical delithiation step. The sloped background made the selection of background points slightly difficult and hence the refinement challenging compared to the starting $\mathrm{LiFePO}_{4}$, where $2 \mathrm{~g}$ of sample was used for the measurement. Nonetheless, a Rietveld method could be performed for both the samples over the complete 2 theta range with good fitting. The unit cell parameters and the atomic positions obtained from the Rietveld analysis for $\mathrm{LiFePO}_{4}$ and $\mathrm{FePO}_{4}$ are close to those reported earlier. ${ }^{13}$

These structural models reported in Tables 1 and 2 were then used for the Rietveld refinement of NPD patterns from electrodes in completely assembled cells, soaked with deuterated electrolyte (Fig. 4), where only the zero, the scale factor, and the peak width parameters were refined. In both cases, a small amount of electrode material $(0.25 \mathrm{~g})$ was used that contained $15 \mathrm{wt} \%$ carbon additive. This resulted in an uneven background of the NPD patterns. Additional high intensity reflections from the $\mathrm{Al}$ container are also visible. Thus, the Rietveld refinement to determine correctly the cell parameters and atomic positions is challenging. A Rietveld refinement could be performed by excluding the Bragg reflections from $\mathrm{Al}$. This however also excludes several peaks from the active material overlapping or close to the Al Bragg reflections. As the primary goal of this study was to design and validate an in situ cell that allows Rietveld refinement of NPD patterns over the complete 2 theta range, to this point it is recommended to start with a good structural model to avoid large errors during the data interpretation (unless a non-scattering container can be used as the sample holder in the in situ NPD cell). In this study, the Rietveld refinement of $\mathrm{LiFePO}_{4}$ NPD pattern after 1st charge showed that $94.5 \%$ of $\mathrm{LiFePO}_{4}$ has reacted to form $\mathrm{FePO}_{4}$. This value is close to $90.5 \%$ expected from the

Table 1 Crystallographic data obtained from Rietveld analysis of starting $\mathrm{LiFePO}_{4}$ sample. Measurement was performed on dry powder in vanadium cylinder. Refined parameters are in italics

$\mathrm{LiFePO}_{4}$, Pnma $, a=10.3279(1) \AA, \quad b=6.0063(1) \AA, c=4.6933(1) \AA$

\begin{tabular}{|c|c|c|c|c|c|c|}
\hline Atom & $\begin{array}{l}\text { Wyckoff } \\
\text { position }\end{array}$ & $x$ & $y$ & $z$ & $B_{\text {iso }}$ & Occupancy \\
\hline $\mathrm{Li}$ & $4 a$ & 0.0 & 0.0 & 0.0 & $1.45(16)$ & 1.0 \\
\hline $\mathrm{Fe}$ & $4 \mathrm{c}$ & $0.2817(2)$ & 0.25 & $0.9753(4)$ & $0.685(11)$ & 1.0 \\
\hline $\mathrm{P}$ & $4 c$ & $0.0949(3)$ & 0.25 & $0.4163(6)$ & $0.685(11)$ & 1.0 \\
\hline O1 & $4 c$ & $0.0971(3)$ & 0.25 & $0.7431(6)$ & $0.685(11)$ & 1.0 \\
\hline $\mathrm{O} 2$ & $4 c$ & $0.4566(2)$ & 0.25 & $0.2073(1)$ & $0.685(11)$ & 1.0 \\
\hline $\mathrm{O} 3$ & $8 d$ & $0.1659(1)$ & $0.0462(3)$ & $0.2836(4)$ & $0.696(26)$ & 1.0 \\
\hline
\end{tabular}

2 theta range/

step increment

Refinement program

Number of measured

reflections

Zero shift

Phases and weight

percentages

Reliability factors

\author{
$0.1^{\circ}-150.9^{\circ} / 0.1^{\circ}$ \\ Fullprof suite version 2007 \\ 489 \\ $-0.2769^{\circ}$ \\ $\mathrm{LiFePO}_{4}(100 \%)$ \\ $R_{\mathrm{p}}=9.39 \%, R_{\mathrm{wp}}=10.1 \%$, \\ $R_{\text {exp }}=3.04 \%, \chi^{2}=11.1$, \\ Bragg $R$-factor $=6.33 \%$
}


Table 2 Crystallographic data obtained from Rietveld analysis of $\mathrm{LiFePO}_{4}$ electrode after $1 \mathrm{st}$ charge till $4.5 \mathrm{~V}$ vs. $\mathrm{Li} / \mathrm{Li}^{+}$. Measurement was performed on dry electrode mass in vanadium cylinder. Refined parameters are in italics

$\mathrm{FePO}_{4}$, Pnma, $a=9.8260(1) \AA, b=5.7941(1) \AA, c=4.7839(1) \AA$

\begin{tabular}{lllllll}
\hline \multicolumn{3}{c}{ Wyckoff } & & & \\
Atom & position & $x$ & $y$ & $z$ & $B_{\text {iso }}$ & Occupancy \\
\hline $\mathrm{Fe}$ & $4 \mathrm{c}$ & $0.2757(5)$ & 0.25 & $0.9492(10)$ & $0.495(56)$ & 1.0 \\
$\mathrm{P}$ & $4 \mathrm{c}$ & $0.0925(9)$ & 0.25 & $0.3923(16)$ & $0.547(59)$ & 1.0 \\
$\mathrm{O} 1$ & $4 \mathrm{c}$ & $0.1181(7)$ & 0.25 & $0.7073(14)$ & $0.547(59)$ & 1.0 \\
$\mathrm{O} 2$ & $4 \mathrm{c}$ & $0.4405(7)$ & 0.25 & $0.1619(15)$ & $0.547(59)$ & 1.0 \\
$\mathrm{O} 3$ & $8 \mathrm{~d}$ & $0.1668(5)$ & $0.0421(9)$ & $0.2463(13)$ & $0.479(54)$ & 1.0
\end{tabular}

2 theta range/

step increment

Refinement program

Number of measured

reflections

Zero shift

Phases and weight

percentages

Reliability factors

\author{
$0.1^{\circ}-150.9^{\circ} / 0.1^{\circ}$ \\ Fullprof suite version 2007 \\ 455 \\ $-0.2745^{\circ}$ \\ $\mathrm{FePO}_{4}(94.5 \%)$ and $\mathrm{LiFePO}_{4}(5.5 \%)$ \\ $R_{\mathrm{p}}=23.7 \%, R_{\mathrm{wp}}=24.1 \%, R_{\exp }=7.69 \%$, \\ $\chi^{2}=9.87$, Bragg $R$-factor $=17.1 \%$
}

electrochemistry. This proves that by using reliable starting structural models a good fitting could be obtained for the NPD patterns recorded using the in situ NPD cell.

Fig. 5 compares the NPD patterns recorded for $\mathrm{LiFePO}_{4}$ electrode at open circuit potential in two completely assembled circular in situ NPD cells, one with protonated EC/DMC $1 \quad \mathrm{M}^{\mathrm{LiClO}_{4}}$ electrolyte (A) and another with deuterated d-PC/d-DMC $1 \mathrm{M} \mathrm{LiClO}_{4}$ electrolyte (B). It is immediately evident that moving to a protonated electrolyte leads to a higher background intensity in the NPD pattern. Most of the peaks from $\mathrm{LiFePO}_{4}$ that were clearly visible when a deuterated electrolyte was used are no longer detectable. Only the most intense peaks of the electroactive material possess a sufficient signal-to-noise ratio to be detected. Nevertheless, to test the feasibility of using much cheaper protonated electrolyte for in situ NPD measurements, the first in situ NPD tests with $\mathrm{LiFePO}_{4}$ electrode was performed using protonated EC/DMC $1 \mathrm{M} \mathrm{LiClO}_{4}$. Every sixth in situ NPD pattern recorded during the electrochemical operation of the in situ cell, corresponding to $10 \%$ of specific charge, has been plotted in Fig. 6. It is seen qualitatively from Fig. 6 that during the course of first charge the peaks corresponding to the $\mathrm{LiFePO}_{4}$ phase disappear, while that from $\mathrm{FePO}_{4}$ emerge. When $50 \%$ specific charge has been withdrawn from the material, both the phases coexist, proving that evolution of different phases can be followed using the circular in situ NPD cell. For the pattern at the end of the first charge, only the intense peaks from the $\mathrm{FePO}_{4}$ are visible. This study on $\mathrm{LiFePO}_{4}$ thus shows that using the inexpensive protonated electrolyte, evolution of the diffraction peaks can be followed qualitatively. However, to obtain well-resolved NPD patterns during electrochemical cycling for quantitative analysis a deuterated electrolyte must be used.
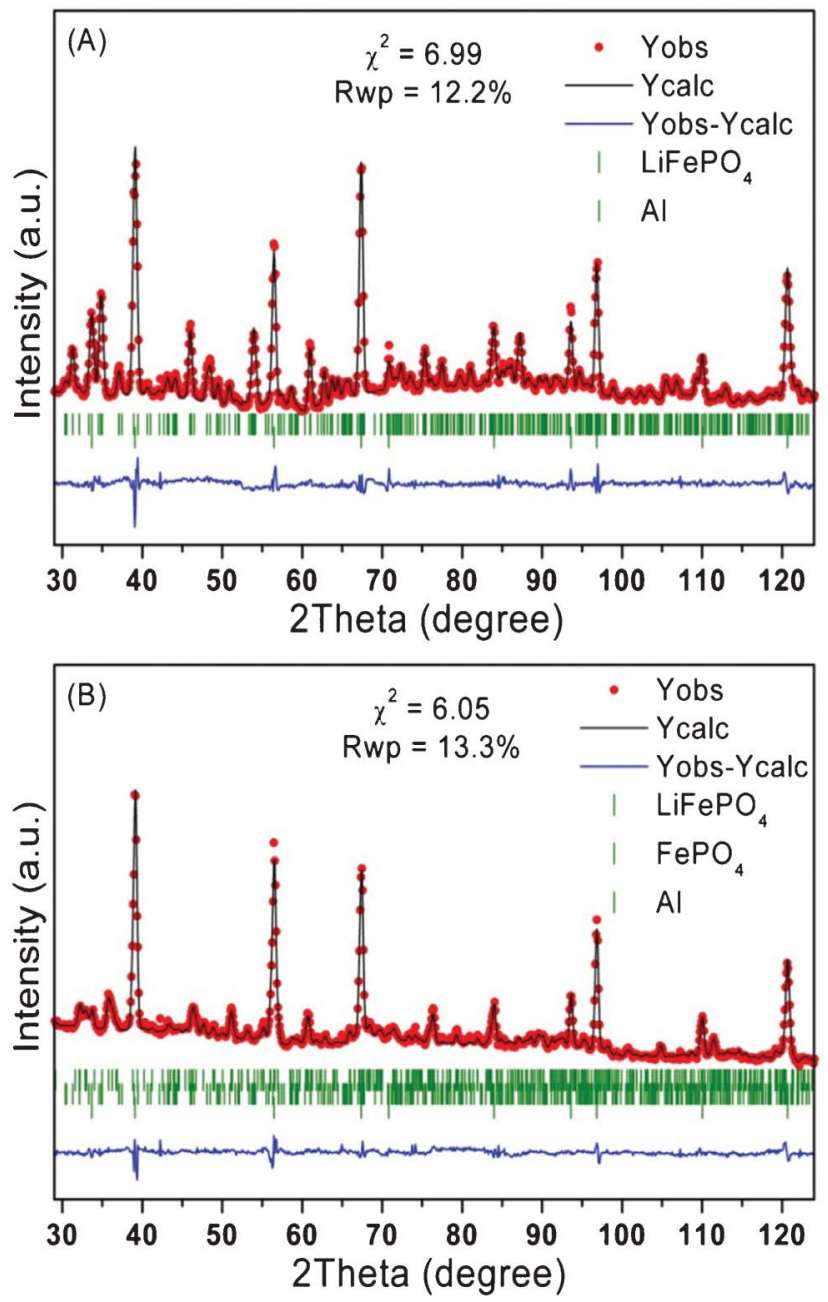

Fig. 4 Rietveld refinement of ex situ NPD pattern $(\lambda=1.36 \AA)$ of $(A) \mathrm{LiFePO}_{4}$ pristine electrode at open circuit potential and (B) $\mathrm{LiFePO}_{4}$ electrode after $1 \mathrm{st}$ charge till $4.5 \mathrm{~V}$ vs. Li/Li+. The samples were soaked in deuterated d-PC/d-DMC 1 $\mathrm{M} \mathrm{LiClO}_{4}$ electrolyte and held in completely assembled circular in situ NPD cell in an aluminum container.

Thus, the second in situ NPD study of graphite in the circular cell was conducted using deuterated electrolyte. The preliminary data has been presented here with the aim of showing the performance of the circular in situ NPD cell when a deuterated electrolyte is used (Fig. 7). The titanium container that was used in order to assist cycling of graphite at potentials negative to $1 \mathrm{~V} v s$. $\mathrm{Li}^{-\mathrm{Li}^{+}}$shows a large number of diffraction peaks due to its hexagonal space group $P 6_{3} / m m c$. However, the major peaks from graphite and titanium do not overlap. From the in situ NPD patterns the main (002) peak is seen to shift to lower 2 theta values, i.e., higher $c$ unit cell parameter, which is expected as also shown by Dahn. ${ }^{14}$ Several other reflections are seen to evolve during the course of lithiation due to the transition to stage $4 \mathrm{~L}, 3 \mathrm{~L}$, and $2 \mathrm{~L}$. Owing to the fact that a deuterated electrolyte was used and that graphite itself is a very good neutron scatterer, the signal/noise ratio was sufficiently high. As no proper crystallographic models are 


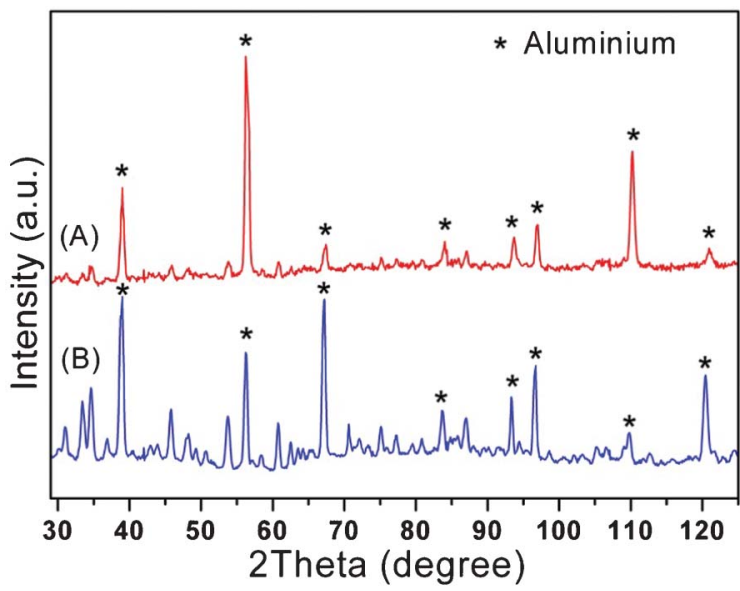

Fig. 5 Comparison of NPD patterns $(\lambda=1.36 \AA)$ recorded over 24 min for $\mathrm{LiFePO}_{4}$ electrode held in a completely assembled circular in situ NPD cell in an aluminum container soaked with (A) protonated EC/DMC $1 \mathrm{M} \mathrm{LiClO}_{4}$ and (B) deuterated d-PC/d-DMC $1 \mathrm{M} \mathrm{LiClO}_{4}$ electrolyte.
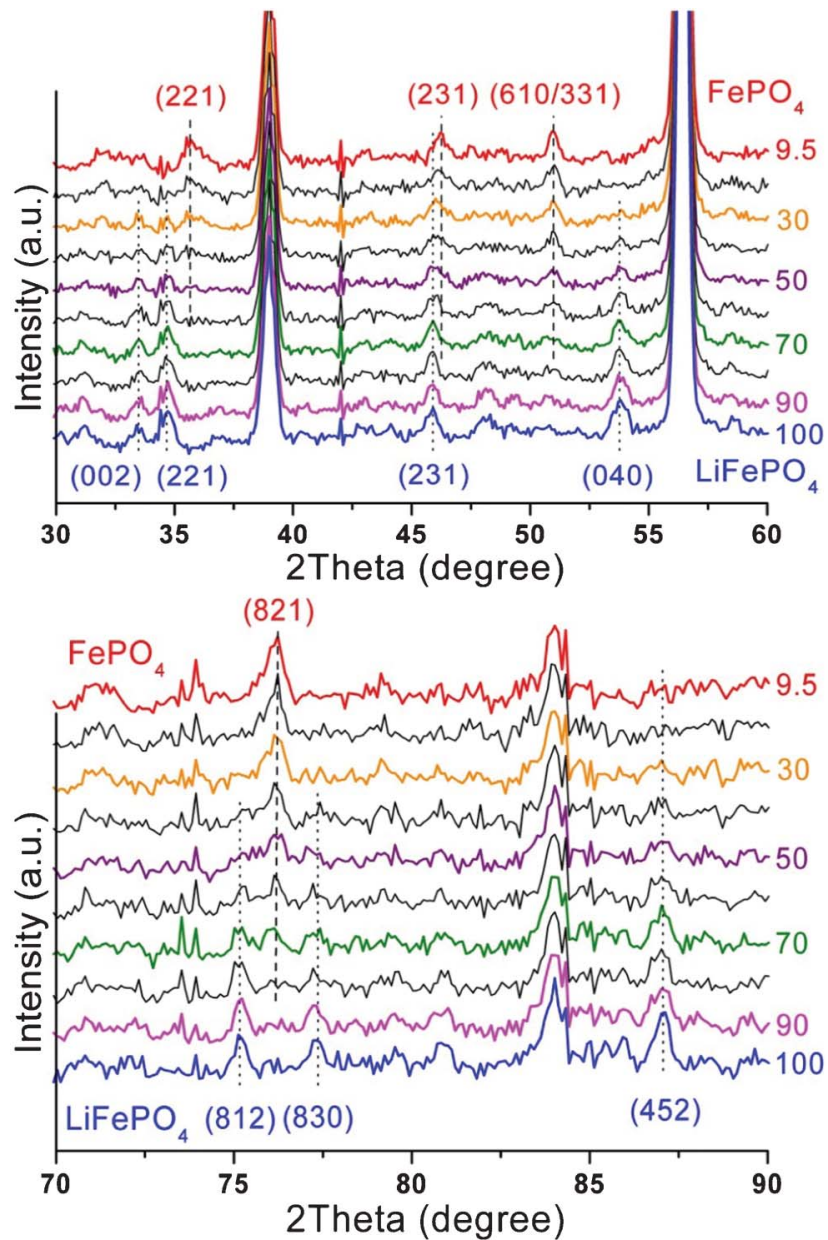

Fig. 6 In situ NPD patterns $(\lambda=1.36 \AA)$ recorded during 1 st charge of $\mathrm{LiFePO}_{4}$ till $4.5 \mathrm{~V}$ vs. $\mathrm{Li} / \mathrm{Li}^{+}$. The numbers on the right-hand side of the patterns represent the nominal percentage of $\mathrm{LiFePO}_{4}$ in the sample as calculated from the electrochemical curve.
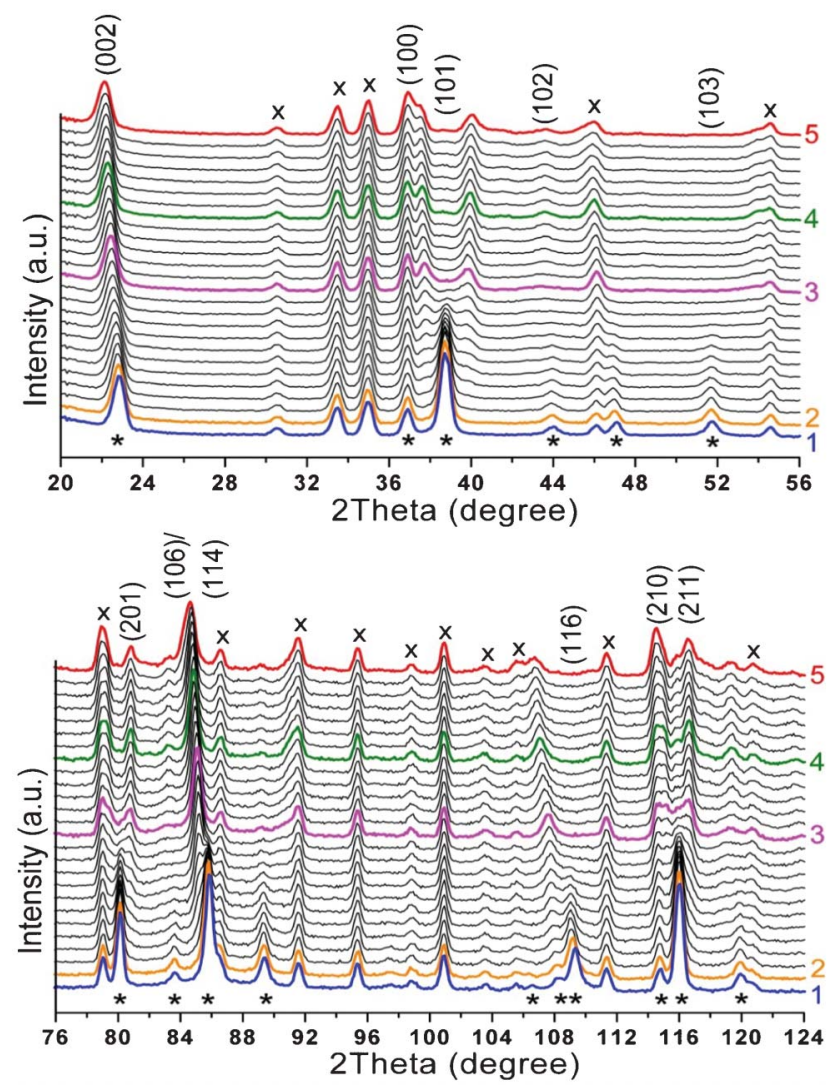

Fig. 7 In situ NPD patterns $(\lambda=1.36 \AA)$ recorded during first lithiation of graphite between $0.23-0.11 \mathrm{~V}$ vs. $\mathrm{Li} / \mathrm{Li}^{+}$. ${ }^{*}$ and $\mathrm{x}$ mark peaks from graphite and titanium, respectively. Major Bragg reflections for graphite are indexed.

available for the different liquid-like stages in graphite, the analysis of the in situ NPD data is still ongoing. However, this example clearly illustrates the feasibility of using the new circular in situ NPD cell design to follow the structural evolution in electroactive materials for Li-ion batteries in real time.

In summary, from the results it can be concluded that Rietveld refinement method can be performed on NPD data from the electroactive material and carbon mixture, filled in a cylindrical sample holder soaked with deuterated electrolyte. A very good and reliable fitting can be obtained if an acceptable structural model is used. However, when a protonated electrolyte is used instead of a deuterated one, fewer peaks from the sample itself are visible. Moreover, the use of protonated electrolyte leads to an increased background and low signal/background ratio, making it very difficult and unreliable to perform quantitative analysis of the data. Thus, if one intends to perform qualitative and quantitative analysis of the in situ NPD data, a pure and dry deuterated electrolyte must be used. Use of protonated electrolyte will only allow for qualitative analysis of evolution of different phases. In terms of electrochemistry the cell was tested for C-rates up to C/10. Cycling at higher rates could be possible but would not be advisable due to challenges with increased electrochemical polarization. 


\section{Conclusion}

A new in situ neutron powder diffraction (NPD) cell based on a circular geometry, capable of cycling $0.2-0.3 \mathrm{~g}$ of electrode mass, was designed and successfully tested at the D20 beamline at ILL, Grenoble, France. From the ex situ NPD measurements, it was concluded that the use of deuterated electrolyte allows for a qualitative and quantitative analysis of the diffraction patterns. Using this circular cell, the first in situ NPD run using $\mathrm{LiFePO}_{4}$ in protonated EC/DMC $1 \mathrm{M} \mathrm{LiPF}_{6}$ electrolyte was successfully conducted at the D20 beamline. As the $\mathrm{LiFePO}_{4}$ was charged at $\mathrm{C} / 24$ rate, NPD patterns were recorded over $24 \mathrm{~min}$, i.e., $0.01667 \mathrm{Li}^{+}$, making it possible to follow the evolution of different phases qualitatively. The in situ NPD experiment performed using graphite soaked in deuterated EC/DMC $1 \mathrm{M} \mathrm{LiPF}_{6}$ electrolyte showed very good electrochemistry and high signal/noise ratio for the NPD patterns. The evolution of several peaks from graphite could be followed qualitatively and analysis is ongoing to identify and quantify the different phases. In conclusion, it can be said that a reliable in situ NPD cell cycling a small amount of electroactive material at faster rates and lower data acquisition time has been successfully developed.

\section{Acknowledgements}

We thank Dr Thomas Hansen, beamline scientist at the D20 beamline, ILL, Grenoble, for his technical support during the neutron powder diffraction measurements. We are grateful to Dr Tsuyoshi Sasaki and Mr Christoph Junker for their help during the experiments and fruitful discussions. We also thank the Swiss National Science Foundation (SNF) for the funding.

\section{References}

1 J.-M. Tarascon and M. Armand, Nature, 2001, 414(6861), 359.

2 Y. Nishi, Chem. Rec., 2001, 1(5), 406.

3 H. Berg, H. Rundlov and J. O. Thomas, Solid State Ionics, 2001, 144(1-2), 65.

4 O. Bergstrom, A. M. Andersson, K. Edstrom and T. Gustafsson, J. Appl. Crystallogr., 1998, 31(5), 823.

5 M. A. Rodriguez, D. Ingersoll, S. C. Vogel and D. J. Williams, Electrochem. Solid-State Lett., 2004, 7(1), A8.

6 N. Sharma, G. Du, A. J. Studer, Z. Guo and V. K. Peterson, Solid State Ionics, 2011, 199-200, 37.

7 F. Rosciano, M. Holzapfel, W. Scheifele and P. Novák, J. Appl. Crystallogr., 2008, 41, 690.

8 J.-F. Colin, V. Godbole and P. Novák, Electrochem. Commun., 2010, $12(6), 804$.

9 V. F. Sears, Neutron News, 1992, 3(3), 26.

10 A. Boulineau, L. Croguennec, C. Delmas and F. Weill, Solid State Ionics, 2010, 180(40), 1652.

11 A. S. Andersson, B. Kalska, L. Häggström and J. O. Thomas, Solid State Ionics, 2000, 130(1-2), 41.

12 H. C. Shin, K. Y. Chung, W. S. Min, D. J. Byun, H. Jang and B. W. Cho, Electrochem. Commun., 2008, 10, 536.

13 V. A. Streltsov, E. L. Belokoneva, V. G. Tsirelson and N. K. Hansen, Acta Crystallographica B, 1993, 49(2), 147.

14 J. R. Dahn, Phys. Rev. B: Condens. Matter, 1991, 44(17), 9170. 